\title{
Réoime transitoire et stabilité du barrage en enrochements de Zlutice
}

\author{
par I. Kazda \\ Katedra Hydrotechniky, C.V.U.T. \\ Prague (Tchécoslovaquie)
}

\section{Résumé}

Les caractéristiques principales du barrage de Zlutice sur la Strela (Bohême N.-O.) sont les suivantes:

- Hauteur maximum au-dessus des fondations $28 \mathrm{~m}$

- Longueur en crête............. $232 \mathrm{~m}$

- Volume total de l'ouvrage............ $212000 \mathrm{~m}^{3}$

- Retenue normale à la cote.......... 310,12

La figure 1 ci-contre donne le profil en travers-type de l'ouvrage. Le noyau étanche, en terre de loess, est incliné vers l'amont suivant une pente de: $1 / 1,8$; il est relativement mince (épaisseur horizontale minimum: $3,20 \mathrm{~m}$ ) et son volume total est de $26000 \mathrm{~m}^{3}$. Durant la construction, il arrivait que la teneur en eau des terres dépassât le maximum admissible; on ajoutait alors, 1 à 2 heures avant le compactage, $40 \mathrm{~kg}$ de chaux par mètre cube de terre.

Les recharges en pierres de granit et de micaschistes $\left(D_{\max }: 50 \mathrm{~cm} ; D_{10}>10 \mathrm{~cm}\right)$ étaient compactées au rouleau vibrant.

Dès sa mise en service en 1969 , à la suite notamment de vidanges relativement rapides, les mesures de pression intersticielles (par cellules électro-acoustiques soviétiques, type NIS-PD) dans l'écran d'étanchéité donnèrent des valeurs nettement plus élevées que celles prévues au projet.

La stabilité du talus amont pouvant s'en trouver menacée, il a été procédé - au moyen d'un modèle mathématique - à l'analyse de l'évolution des pressions intersticielles en divers points critiques, en fonction de la rapidité de variation du niveau du plan d'eau dans la retenue.

Le mémoire analyse en détail — avec graphiques à

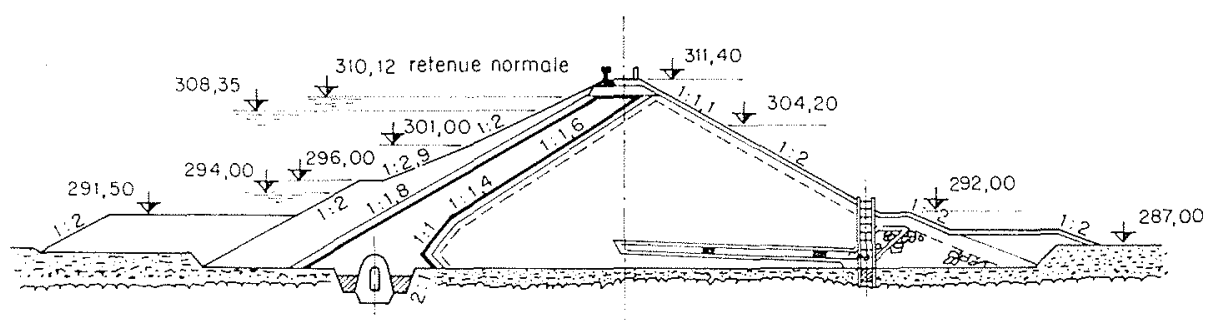

$1 /$ 
l'appui - les valeurs mesurées par les cellules de pression intersticielle au cours de l'évolution du niveau dudit plan d'eau et les compare tout d'abord à celles déduites de la formule de Skempton-Bishop (vidange rapide) et plus généralement au modèle mathématique établi par M. Kazda.

En conclusion, ces études ont conduit à des consignes d'exploitation limitant la vitesse de vidange du réservoir à :

- $20 \mathrm{~cm}$ par jour entre la R.N. et la cote 296.00;

- $15 \mathrm{~cm}$ par jour entre les cotes 296 et 291,50;
- $15 \mathrm{~cm}$ par jour au-delà, sous réserve de vérifier que les pressions intersticielles ne dépassent pas les limites admises.

Les mesures effectuées en exploitation, depuis la mise en vigueur des consignes ci-dessus, ont mis en Iumière la consolidation du noyau et la réduction des pressions intersticielles au sein de ce dernier.

N. B. - Le texte (en français) in extenso du mémoire de M. Kazda peut être consulté dans les bureaux de la S.H.F., 199, rue de Grenelle, 75007 Paris.

\section{Abstract}

\section{Transient conditions and stability of the Zlutice rock fill dam}

The leading particulars of this dam on the river Strela in North-west Bohemia are as follows:-

Maximum height above foundations ........ $28 \mathrm{~m}$

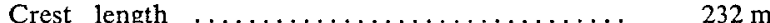

Total volume of structure $\ldots \ldots \ldots \ldots \ldots \ldots \ldots 212,000 \mathrm{~m}^{3}$

Normal storage level ............... $310.12 \mathrm{~m}$

Fig. 1 shows a representative cross-section of the dam. The impermeable loess earth core slopes upstream at $1.8: 1$. It is comparatively thin, with a minimum horizontal thickness of $3.20 \mathrm{~m}$ and a total bulk of $26000 \mathrm{~m}^{3}$. During construction of the dam the ground water content sometimes exceeded the permissible quantity, in which case $40 \mathrm{~kg}$ of lime were added per cubic metre of earth one or two hours before compacting.

The granite rock and mica-shale (up to $50 \mathrm{~cm}$ size, $\mathrm{D}_{10}>10 \mathrm{~cm}$ ) fill was vibro-compacted by roller.

After the dam went into service in 1969 voids pressure measurements in the impervious curtain with Russian NIS-PD electro-acoustic cells gave values well above the design data, especially after relatively rapid emptying.
In view of the possible threat to the stability of the upstream embankment, a mathematical model study was made of pore pressures at critical points for various rates of storage level variation.

The report presents a detailed analysis with graphs of pore pressure values measured by pressure cell at varying storage levels and compares these values with theoretical data calculated by the Skempton-Bishop formula, and more generally, data obtained with the aid of Author's mathematical model.

As a result of the investigations, operating instructions were compiled which set the following limits to the reservoir emptying rates:

20 centimetres daily between normal storage level and 296.00 ; 15 centimetres daily between 296.00 and 291.50;

15 centimetres daily beyond 291.50 , subject to pore pressures not exceeding the permissible values.

Measurements made since these instructions became effective have shown that the dam core has consolidated and that the pore pressures within it have been reduced. 